\title{
High-rise in trouble? Learning from Europe
}

\author{
Paul van Soomeren (DSP-groep, Amsterdam, The Netherlands) \\ Willemijn van de Klundert (WvdK Architectural Services, London, UK) \\ Inés Aquilué (Universitat Politècnica de Catalunya, Barcelona, Spain) \\ Justin de Kleuver (DSP-groep, Amsterdam, The Netherlan)
}

\section{Abstract}

\section{Purpose}

All over the world, millions of people live in buildings and neighbourhoods that follow the principles of Congrès International d'Architecture Moderne (CIAM) and Le Corbusier: high-rise "residential machines" in parks reminiscent of green seas. Some of these have become very successful living environments, but in Europe and the USA, several neighbourhoods featuring this architectural design dream have become a social nightmare. Residents who were able to moved to more desirable neighbourhoods. This led to a high level of vacancy and crime and fear of crime have flourished, resulting in a stigma that is often long-lasting and difficult to repair. The pupose of this study is to learn from these experiences.

\section{Design/methodology/approach}

In this paper, two high-rise neighbourhoods, built in a Corbusier-like fashion and situated on the outskirts of major cities, are put under the evaluation spotlight: Bijlmermeer: located in Amsterdam, The Netherlands, with an abundance of landscaping, shrubbery, green fields and one high-density neighbourhood; and Bellvitge: located in Barcelona, Cataluña, Spain, looking less like a park and more like a city with open-air parking on ground level, and many small shops, bars and restaurants.

\section{Findings}

Both neighbourhoods faced enormous problems from crime, incivilities, disorder and drug abuse. Fear of crime and feelings of insecurity were high. Both governments reacted by investing huge sums of money. In Bellvitge, the investment was mainly in public transport, the public domain and new approaches in policing while keeping the high-rise buildings intact. In Bijlmermeer, a large regeneration project supported the demolition of two-thirds of all apartments and the neighbourhood was rebuilt in a low-rise fashion. 


\section{Research limitations/implications}

This paper outlines the history of both neighbourhoods and describes the solutions that were implemented. Important lessons can be learned regarding current high-rise neighbourhoods and about the learning capacity of urban designers and planners regarding urban management.

\section{Practical implications}

The paper suggests that urban planners, designers and managers are slow in learning from earlier mistakes. The hypothesis is that there is no clear method available to evaluate new urban planning designs by incorporating lessons from the success or failure of previous cases. This paper focuses on density, ownership and design to identify possible approaches to evaluate new high-rise estate plans.

\section{Originality/value}

The Western high-rise "wave" has faded away but nowadays has become a high-rise "tsunami" in Asia. Learning from European experience may be beneficial.

\section{Keywords}

Design, Urban, Bellvitge, Bijlmermeer, High-rise

\section{Paper type}

Case study 


\section{Back to CIAM}

In 1933 a famous conference of world-leading urban planners and architects was held on a steamer sailing between France and Athens. It was the fourth time the group, known as Congrès International d'Architecture Moderne (CIAM), had gathered. The theme of their discussion was 'The Functional City' and the results of this conference were summarized ten years later by the Swiss architect Le Corbusier in the Charter of Athens (La Charte d'Athènes). The charter is divided into observations and recommendations (De Villeneuve-Esclapon Aubigny (Baronne d') et al, 1943). CIAM was fighting against the extremely dense, polluted and unhealthy situation that existed in most cities. Light, air and space was seen as the solution - as well as segregation of transportation routes for vehicles and dwellings. Each dwelling "will rise in its own surroundings, in which it will enjoy sunshine, clear air, and silence." Decisions about urban density were seen as of the utmost importance: "To determine the urban densities is to perform an administrative act heavy with consequences" (CIAM 25; recommendation).

Nowadays there is a great deal of ignorance around the issue of urban density. It is often assumed that high-rise always equals high density. This might be the case in some countries (particularly in Asian countries) and in city centres but it is certainly not the case for all suburban high-rise apartment blocks. Take, for example, the Amsterdam neighbourhood of Bijlmermeer - an example of Le Corbusier thinking put into practice. In Bijlmermeer, high-rise equals very low density as compared to Bellvitge where the density is four times higher (table 1).

In this respect the designers of Bijlmermeer followed the advice of the CIAM architects and planners who recommended this lower density as they opposed the existing malaise of damp, unhealthy cities built in extremely high density with narrow streets that did not allow for air, light and space: "High buildings, set far apart from one another, must free the ground for broad verdant areas. Indeed, they will have to be situated at sufficiently great distances from one another, or else their height, far from being an improvement of the existing malaise, will actually worsen it" (CIAM 29; recommendation).

An abundance of public space is inevitable when the CIAM requirements 'low density' plus 'high-rise' are being followed. Most planners and designers, and also 'non-CIAM adepts', favour public space. This can also be said of most urban sociologists, local politicians and authorities. Only urban managers might be a little less naïve since they have to clean, repair and manage public space. They know that due to high costs this abundant public space is often not very well surveyed, maintained or managed. Often there is simply too much public space causing a dispersion of people and residents, as well as police and other officials. As there are not many eyes surveying the public space, nor many hands defending or maintaining that space, 'control' becomes a problem (Jacobs, 1961; Habraken, 2000).

The CIAM ideas had a great deal of value because cities were indeed too dense, polluted, noisy and unhealthy. However their solutions may have been too extreme, resulting in simply too much public space that was impossible to survey and maintain. The lack of surveillance and no opportunity for feelings of territoriality to flourish resulted too often in feelings of insecurity and fear of crime. But even worse, these neighbourhoods were often plagued by too many real crimes such as robbery and violence. 


\section{Two case studies: Bijlmermeer and Bellvitge}

We have studied two typical CIAM neighbourhoods - Bijlmermeer in Amsterdam and Bellvitge in Barcelona - to learn more about current high-rise neighbourhoods in Western Europe and to explore lessons that may be applied to high-rise developments in Asia. Both follow the CIAM high-rise principles but the Bellvitge neighbourhood has a far higher density (refer to table 1).

Table 1: Comparison Bellvitge and Bijlmermeer //table equals 85 words//

Notes IN the table:

Note 1 Figures by Aramburu et al., 2009 for the year 1991

Note 2 Figures taken from the 'De Bijlmermonitor 2010' for the year 1994 (before renovation); the surface is an estimate (T93+T34 minus Venserpolder, Geerdinkhof, Groenhoven, Gouden Leeuw and Garstkamp)//

The two cases have a common urban form, and a development that differs in relation with the resident community of each settlement. Both cases developed a high crime rate, and specific measures were applied to address this.

In these case studies we have further explored the relationship between the CIAM recommendations of low density and high-rise on the one hand and fear of crime, feelings of insecurity and crime on the other. Both neighbourhoods have suffered a lot from crime and fear of crime though somehow both high-rise estates have managed to survive to overcome these problems. The regeneration of each neighbourhood was approached differently:

- In Bijlmermeer the solution was extreme and rather costly: demolishing two-thirds of the high-rise at a cost of about one and a half billion euro.

- In Bellvitge the investment was mainly on the ground floor level in the public domain (drainage, water, streets and lighting) with a strong focus on new approaches to policing (community policing) and on creating an inviting and friendly public space containing many small shops and restaurants.

These high-rise settlements are not isolated cases; at the time they were being developed urban planners and designers all around the world were planning high-rise buildings inspired by CIAM and Le Corbusier's urban concepts. The Western high-rise 'wave' faded away (Turkington et al., 2004) but nowadays has become a high-rise 'tsunami' in Asia. Learning from European experience might thus be useful.

\section{Foundation of the estates, building design and urban structure}

In 1964 a high-rise neighbourhood for the working classes called Bellvitge was founded in the city of Hospitalet de Llobregat, near Barcelona. The construction of this estate commenced two years before the start of the development of Bijlmermeer, a high-rise settlement in the southeast of 
Amsterdam. They were both huge estates, and in both cases were located in isolation on the city periphery. Although both housing developments were constructed around the same time and were designed as 'functional towns', the future of each settlement progressed quite differently.

\section{Bellvitge}

\section{Photo 1: Bellvitge}

Due to the industrial development of Cataluña - at that time dominated by SEAT and Telefónica - a large number of people from other Spanish regions moved to the city of Barcelona (Aquilué and Stummvoll, 2014). More housing was needed and Bellvitge was initially constructed as a development of 7,000 dwellings for approximately 30,000 inhabitants.

Bellvitge was built on a flood plain of $2.8 \mathrm{~km}^{2}$ (only $0.73 \mathrm{~km}^{2}$ of which was urban residential) with construction work finalized in 1980 (Associació de Veïns de Bellvitge, 2005). The urban design was based on fifteen floors of prefabricated high-rise concrete slabs. The dwellings on each floor were connected to lift columns, forming the structure of each block. When the blocks of the first settlement, South Bellvitge, was finished there were no paved streets, public spaces, facilities such as schools, or drainage systems in place. Only rectangular prefabricated high-rise slabs were visible on the landscape and flooding was common during the wet seasons. The dwellings were made available for the owner-occupier market.

On completion Bellvitge consisted of sixty-five building blocks and five towers containing 9,138 dwellings and 32,605 inhabitants. The density of the residential area was 44,600 inhabitants per $\mathrm{km}^{2}$ (residential area: $0.73 \mathrm{~km}^{2}$ ). In 1956 the original plan was for 7,000 dwellings but due pressure from private developers the density was increased, causing a great deal of controversy among the first residents (table 1 ).

\section{Bijlmermeer}

Bijlmermeer was also built in the 1960s catalyzed by the post Second World War housing shortage. Lack of building during the Second World War, war damage, poor existing housing stock, and migration into large cities partly caused by a labour shortage resulted in a need for new housing construction. Bijlmermeer was a residential development on an unprecedented scale in the Netherlands. Designed by the young architect Siegfried Nassuth, It was initially planned to be home to 100,000 people and was developed by urban planners and architects of the city of Amsterdam for the social sector rental market.

\section{Photo 2: Bijlmermeer}

Construction of Bijlmermeer started in 1966 and was finished when the last of the dwellings and shopping centres were completed in 1975. The area had 17,000 dwellings of which 13,000 were located in 31 large high-rise social housing blocks. The urban structure of the settlement was composed of ten-storey deck-access apartment blocks in a honeycomb pattern between which were 
large green spaces and bicycle and pedestrian routes. The traffic was separated from these on elevated roads that created a large number of dark viaducts, which came to be perceived to be unsafe (Soomeren, Bijlmermonitor 1997-2009, Wassenberg 2006 and 2013).

Bijlmermeer was a high-rise settlement, but the density was very low. It was the opposite in Bellvitge were the density was - and still is - approximately four times higher than that of Bijlmermeer. Even if the original plan for Bellvitge had been executed (7,000 dwellings) the density would have been approximately three times higher as compared to Bijlmermeer.

When comparing the urban structure of both settlements, the main differences between the two high-rise developments were density (inhabitants and dwellings per $\mathrm{km}^{2}$ ), the distance between the building blocks and the number of dwellings. The number of dwellings and the distance between the blocks was higher in Bijlmermeer and the density lower. Furthermore, there was another variable: the separation of function regarding traffic. In Bijlmermeer there was complete separation between pedestrian and bicycle traffic on ground level and cars at first floor level. The main roads for cars were directly connected with the buildings through parking garages connected to the roads', while in Bellvitge cars and pedestrians were all at ground level. In Bellvitge cars are parked in the spaces between blocks, where there was a high level of social control. Another difference was that in Bijlmermeer dwelling entrances were accessed through interconnecting corridors, whereas in Bellvitge the use of single lifts connected to only a few apartments on each floor provided higher social control in the limited common areas inside the buildings.

Bijlmermeer was an area entirely developed by the urban planners and architects of the city of Amsterdam (Klundert, 2014), whereas Bellvitge was established by private investors. In Bellvitge, most inhabitants were low-income workers who owned their apartments while the apartments in Bijlmermeer were mostly owned by housing associations and rented out in the social rent sector.

\section{Socio-demographics}

Gifford (2007) concludes: "Thus, high rises may have positive or negative effects on those who live in them, depending not on building height alone (the defining characteristic of high rises), but on at least eight other moderating factors." Gifford outlines moderating factors such as economic status, the amount of choice of dwellings a resident has, the location of a building within the urban fabric, population density, dwelling design and a resident's life stage, gender, and culture. This list is a mix of physical and social factors and the moderating factors are most likely different in each case. But as Jane Jacobs (1961) once remarked: "We expect too much from new buildings and too little from ourselves." Hence it is obviously important not only to look at the physical features of new neighbourhoods but also at the social dynamics.

\section{Bellvitge}


Five decades ago when the original slabs of Bellvitge were laid, the first apartment owners originated from other regions of Spain and were made up mainly of young people (predominantly young families and couples) who wanted to start a new future in the recently developed industries of Barcelona. These residents raised their families in Bellvitge and due to the lack of existing facilities they founded the Housing Association ii of Bellvitge ${ }^{i i i}$. Post Franco they also became part of some wellknown trade unions (Associació de Veïns de Bellvitge, 2005). In most cases, the ownership of the dwellings belonged to the same family for decades (Aquilué and Stummvoll, 2014).

In the 1990s the population of the neighbourhood began to decrease. According to the 1991 Census the population of Bellvitge was 32,605 inhabitants whereas ten years later the population was 26,244, a decrease of approximately 20\% (INE, 1991 and 2001). This reduction however never resulted in high numbers of vacant dwellings. During the 2000s the number of inhabitants was rather stable and in 2012 the population was 25,528.

In the 2000s the population of Hospitalet de Llobregat itself greatly increased due to immigration, largely from Latin America and Africa. Bellvitge experienced a moderate level of foreign immigration, with the level being $16 \%$ lower than in Hospitalet de Llobregat ${ }^{\text {iv }}$ as a whole (Ajuntament de l'Hospitalet, 2001, 2003, 2012).

\section{Bijlmermeer}

When Bijlmermeer was built the number of inhabitants grew rapidly between 1969 and 1975. After this quick initial growth the area did not expand as fast as the municipality had expected. Also, the influx of people was made up of fewer middle class families than was foreseen. Most of the tenants were one-parent families, singles and couples without children, generally people who had problems finding a home elsewhere in the Netherlands due to a waiting list system. Many people came from Surinam and the Dutch Antilles, former Dutch colonies. At the same time, an influx of illegal immigrants created overpopulation in some of the blocks. The residents of Bijlmermeer often experienced problems with language, education, social and economic status, discrimination, isolation from other ethnic groups and unemployment was also high (Wassenberg, 2006).

These social problems created bad publicity and in the 1980s the percentage of vacant dwellings rose to $20-25 \%$ : one out of nearly every four dwellings was deserted. As with Bellvitge the population decreased further during the 1990s, mainly because of an ageing population. In Bellvitge however, a different situation prevailed, the building disadvantages created a tight social cohesion among the mostly Spanish residents and the population reduction did not result in many empty dwellings due to the apartments there being largely privately owned. Ownership seems to be a crucial variable here. 


\section{Crime, conflict and fear}

In both neighbourhoods crime and fear of crime were at some point common issues.

Despite positive social cohesion amongst the residents of Bellvitge, intensified by the economic crisis of the 1980s problems increased, and the neighbourhood acquired its bad image. Conflicts became common due to high unemployment and an increase of drug addiction among young people (mainly heroin). Crime rates, social disorder, violence, robberies, drug-use and vandalism all increased significantly.

Similarly, in the Netherlands in the 1980s and even more extremely in Bijlmermeer, there were growing crime and economic crises. Drug problems, also mainly heroin-related, spiralled out of control due to the displacement of these problems from the city centre to Bijlmermeer. There were also more issues: less people than expected moved to Bijlmermeer; more were singles rather than families; a high percentage of residents from outside the Netherlands arrived to a cold, urbanized high-rise area; there were limited facilities such as shops and schools and limited public transport. A light rail connection between Bijlmermeer and Amsterdam city centre became operational only at the beginning of the 1980s, several years after the high-rise was ready. The paradox was however that the better connection to the city centre eventuated in more drug related problems in Bijlmermeer. All in all, the neighbourhood had a higher crime rate (Dijk and Soomeren, 1986), higher levels of fear of crime and a terrible image among the Dutch population (Hootsen, 2006). Stigmatizing publicity in newspapers, television, and film did not do Bijlmermeer's image any good.

In Bijlmermeer the urban design did not help either. The large number (more than $80 \%$ ) of semipublic spaces - areas like entrances, alleys, corridors, storage spaces, galleries and parking spaces turned into potentially dangerous places (Wassenberg, 2013; Klundert, 2014). "The image of the Bijlmermeer as the city of the future deteriorated: the dream of a functional town became a nightmare of vacant dwellings, drug abuse and a crime ridden area." (Soomeren, 1995, p.11)

\section{Measures and their effects}

In both cases the local governments decided that major action to address the problems was needed.

In 1986 Barcelona gained the candidature to be the site of the 1992 Olympic Games. Local governments of the metropolitan area and the national government decided to improve the city and to solve the safety and security problems. The city of Hospitalet received funding and invested this in some of its degraded neighbourhoods such as Bellvitge. They improved the drainage system, reconstructed the water management system to prevent floods, built a new metro station, developed public space and extended the public transport system. The local population continued their fight during these years to make sure the money was well spent and the planned facilities were built. Bellvitge became a well-connected neighbourhood with attractive public spaces between the building blocks (Aquilué and Stummvoll, 2014). 
All over the metropolitan area a plan against drug dealing and in particular heroin dealing was implemented. In 1985 'the National Plan against Drugs' was approved by the Spanish Government, a scheme that was both repressive and therapeutic. The policies against drug use and trading became harsher and the punishments became more severe. On the other hand, new social care facilities and services for addicts were implemented (Instituto de Criminología, 1986).

In Amsterdam the drug approach was similar, although it was probably a more health centred approach (e.g. methadone treatment) with day care facilities for drug addicts coupled with very strict policies and policing on hard drug trading and a more lenient approach towards soft drugs ${ }^{v}$.

In Bellvitge/Hospitalet the local police concentrated their efforts on community policing activities, which included public order management in close cooperation with departments of the municipality and the establishment of connections with social services, public services and community associations.

In Bijlmermeer the police activities over the years were more or less the same as in Bellvitge/Hospitalet. Furthermore there were two intensive and integrated attempts at improving the area: an initial rather light sweep of improvements followed by a second very intensive one: demolition.

Firstly, between 1985 and the beginning of the 1990s, a set of measures was implemented in Bijlmermeer, based on the CPTED ideas: Crime Prevention Through Environmental Design (Jeffery, 1971; Newman, 1972; Kube, 1982; Crowe, 2013). Most of them were related to the improvement of the physical and technical environment: apartments were split up into smaller units; rents were lowered; some parts of the buildings such as car parks and storage spaces were demolished or converted into homes; some public areas were converted into plots of land; parking was made possible at ground level; anti-burglary devices were installed; lighting was improved; and some of the long galleries were closed.

Most of these measures were successful and it became more difficult to commit vandalism and behave disorderly (Soomeren, 1995). But the continuous rise in levels of unemployment and the increase of certain types of crime such as burglary and the problems associated with drug abuse meant that the expected overall improvement did not eventuate.

At the beginning of the 1990s a plan was formulated to further improve the situation in Bijlmermeer (Wassenberg, 2006). The renewal process was based on two elements: spatial renewal and social renewal.

It was decided that a large part of the high-rise blocks was to be demolished: 6,500 of the 13,000 high-rise dwellings. The demolished apartments were replaced by low-rise housing, $70 \%$ of which were in the private sector and $30 \%$ were social housing. Furthermore, the remaining high-rise blocks were renovated, the interior and elevated walkways removed and ground-floor storage areas replaced by housing. An important change was the demolition or change of use of most of the car 
parks and the lowering of the elevated primary roads to ground level. In that respect the 'new Bijlmermeer' more closely resembled Bellvitge.

\section{Photo 3: H-buurt1}

Photo 4: H-buurt2 //one of these two photos may (!!) be deleted; up to Ares//

The second element was social renewal, which worked on the socio-economic aspect of the Bijlmermeer degradation. There were measures implemented for reducing unemployment, immigrants received training in Dutch language, new social and cultural facilities were created, three primary schools were restructured and important changes in the managerial system of the housing association were introduced. The approach in Bijlmermeer was extremely well monitored in an annual, later bi-annual, evaluation/monitoring assessment (Soomeren, Bijlmermonitor; Klundert, 2014; Wassenberg, 2013)

The measures implemented in Bellvitge were quite different. The focus was not so much on renewal but on building facilities that were initially planned but never built, improving public transport and thereby connection to the city and on enhancing the public spaces. Whereas in Bellvitge the high-rise buildings themselves had resisted the test of crime and drug dealing, in Bijlmermeer they had not.

The effects of these completely different approaches were in both cases positive and the crime rates and the fear of crime decreased. The image of both neighbourhoods was also improved though both neighbourhoods are still stigmatized. More information can be found on the two case studies in Aquilué Junyent et al. (2014) and Soomeren et al. (2014). 


\section{Conclusions and discussion}

\section{Two cases: conclusions}

Two high-rise neighbourhoods, both built in a Corbusier-like fashion. One low density with an abundance of park landscaping (Bijlmermeer, Amsterdam, the Netherlands) and one high density neighbourhood looking less park-like and more like a city with parking on ground level in open air, and a lot of small shops, bars and restaurants (Bellvitge, Barcelona, Cataluña, Spain).

In Bellvitge all apartments were privately owned thus building a 'community of interest' (Newman, 1980) with involvement of the residents leading to territoriality. The high social cohesion and sense of community in Bellvitge was a feature since the foundation of this neighbourhood, a feature which is still present. In Bijlmermeer all apartments were rented out by distant managed housing associations to people who couldn't find residences elsewhere due to long public housing waiting lists.

Both neighbourhoods faced enormous problems with crime, incivilities, disorder and drug abuse. Furthermore fear of crime and feelings of insecurity were high in both neighbourhoods. Both local authorities reacted by investing a lot of money. In Bellvitge the investment was mainly in public transport, the public domain (drainage, water, streets and lighting) and - for Cataluña/Spain - new approaches in policing (Aquilué and Stummvoll, 2014).

This type of approach was also used in Bijlmermeer but proportionally the investment in demolishing still functional and valuable apartments and rebuilding low-rise buildings instead was far higher: in the end 6,500 flats were demolished and rebuilt in a low-rise fashion. This large-scale demolition of buildings was not only due to crime-related issues but also because there were simply too many of these non-traditional and unpopular high-rise buildings in the Amsterdam regional housing market ${ }^{\mathrm{vi}}$. The Dutch solved the problem but it was an extremely costly solution: the redevelopment cost one and a half billion euro.

\section{Lessons learned}

One of the most important lessons learned is that there are many, or at least two, roads to victory. Both high-rise neighbourhoods were able to overcome their problems of crime and fear of crime/feelings of insecurity ${ }^{\text {vii }}$. In both cases the solutions were quite costly and the Bijlmermeer solution - knocking more than half of a relatively new neighbourhood down and rebuilding it in a low-rise style - was extremely costly.

Whatever the costs involved, the overwhelmingly important lesson in both cases is that poor design is extremely costly in terms of maintenance and management. Hence it's worthwhile investing in good urban planning design to make place management easier and better.

A few differences between Bellvitge and Bijlmermeer are worth highlighting.

Ownership of houses, and thus also 'ownership' of the public space, is obviously very important. In Bellvitge there was, and still is, a strong 'community interest' of homeowners who look beyond their own apartment and also have a strong vested interest in the public space. This is even more 
important in Bellvitge since resident's cars were parked in the public space near the apartments, as compared to Bijlmermeer where cars were stowed away in closed parking buildings at a distance from the apartment buildings.

Car and traffic management do focus our attention on another issue: the monotonous public space. Compared to lively Bellvitge with its roads and cars on ground level, multiple shops, bars and restaurants, Bijlmermeer was a dull grey monotonous neighbourhood. The buildings were indeed like grey ships floating in a park-like green ocean. This may be the preference of many planners and (landscape) architects but most people would feel insecure in such a vast space. Residents like to see others and like to be seen. A concentration of diversity (people, shops, restaurants) is what appeals to the majority of people (Soomeren et al., 2014).

One last conclusion is that high-rise as such is not the problem, low density is. Low density often results in deserted public space and hence in feelings of insecurity, fear of crime and also in real crime (Anom, 2008). Furthermore, low density usually consumes territory in an unsustainable manner, making it extremely expensive to build both facilities and infrastructure.

\section{The legacy of Le Corbusier: problems ahead in Asia?}

The legacy of Le Corbusier is widespread. In Western Europe the French banlieues come to mind, in Eastern Europe the communist era building blocks are examples of a central planning doctrine (Lukas, 2007) and also in the UK and USA several estates are notorious. In London, for example, the Holy Estate and the Aylesbury and neighbouring Heygate Estates have had continuous negative publicity. These last two estates have been, against the wishes of the residents, repeatedly negatively depicted in several films and documentaries (Campkin, 2013). Both areas are currently part of a large regeneration project.

//Photo may (!!) be deleted, or used elsewhere in the magazine; up to Ares//

In the USA the Pruitt-Igoe public housing complex in St. Louis is a notorious example. Photo 6: PruittIgoe //see bove: photo may be deleted or used elsewhere//

It was completed in 1955, showed signs of degradation and vacancies soon after construction and has not stood the test of time: demolition started in 1972 and the complete site was cleared in 1976. 
The enthusiasm for high-rise residential buildings has shifted to Asia. Photo 7: Asia Here the principles of Le Corbusier are still applied, although the functionality of the design seems even more pronounced and the towers are higher; in Hong Kong, Seoul and other Asian capitals up to fifty floors high. High-rise living in Asia is seen in a far more positive light than in Europe (Yuen, 2011). The Asian high-rise often reaches very high density and most of it is privately owned. On the other hand the lack of diversity and the monotonous design may be a serious risk in the long term when social bonds, values and norms become more relaxed. Asian high-rise in trouble is not just one neighbourhood in trouble - as in Bijlmermeer and Bellvitge.

\section{Epilogue: do planners and designers learn?}

Do designers and planners learn from earlier plan implementation? In general this seems to be a difficult task (Pressman and Wildavky, 1973). Certainly in the case of urban planning and design real structural learning seems to be difficult. In his foreword for the Crime Prevention Carousel report (Lukas, 2007), in which researchers from five European cities discussed crime in relation to high-rise housing estates, architect Nico Zimmerman (2007) remarks: “After nearly a hundred years of renewal in architecture and urban building it may be a cause for wonder that the unacceptable inner-city forms which were then rejected (PvS: by CIAM) have become an inspiration for urban planners in their search for new diversity and shapes in the compact city. It illustrates the temporary blindness that invariably accompanies revolutionary ideas. While innovation sometimes leads to improvement it is nearly always also coupled with rejection of what was essentially valuable and needed to be cherished." Indeed, the CIAM planners and designers may have kept on building in their revolutionary way if it wasn't for a simple journalist from Greenwich Village appearing on the scene. Jane Jacobs, who revolutionized urban planning, cherished diversity, eyes on the street and mainly people and living before buildings (Jacobs, 1961).

In the case of Bijlmermeer, Igor Roovers, the main planner for the recently developed Amsterdam new town of IJburg, who was also involved in Bijlmermeer for several years, draws an even harsher conclusion: "We never learn any lessons, we should, but we do not take enough time to reflect". In an interview (Soomeren et al., 2014) Roovers indicated that it would be an advantage if all those involved in heading such large projects were interviewed to evaluate their experience and publish their findings. Although during the interview Roovers clearly showed that he, as well as other designers and planners, had learned from earlier experiences (such as Bijlmermeer), these lessons seemed to stay rather implicitly with only one designer or planner. So it is individual learning and not collective learning. There exists no collective post-project evaluation laid out for future projects and future generations. In that respect planners, designers and architects are still artists delivering huge pieces of art in which several thousand people have to live. After designing and delivering one piece of art - a neighbourhood or even a new Chinese city - they 'job-hop' to a new revolutionary artistic highlight, leaving their designs to the residents and urban managers. There is no structural learning cycle that ploughs back the knowledge and experiences from residents, users and urban managers to planners and designers.

Picture 1: PDDE-structural learning cycle 
It would be too simple to blame only urban planners and designers for this. It would also be too simple to blame only urban managers. What is lacking is the will, the structure and the methods to evaluate and learn from experience. We could blame politicians for this serious defect. On the other hand, politicians are only in charge for five to ten years at most. The circle from planning, design through to management and building practical experience by 'living (in) the plan and design' overarches any democratic life cycle of a politician. A glitch in the system perhaps?

Indeed, it seems that residents, users and urban managers have to learn by themselves.

\section{Sources}

Ajuntament de l'Hospitalet. (2001, 2003, 2012) L'Hospitalet. Anuari Estadístic de la Ciutat 2001, 2003 and 2012. Hospitalet de Llobregat (Barcelona): Ajuntament de l'Hospitalet. Available in: http://www.I-h.cat/laciutat/265286_1.aspx?id=1\#

Anom. (2008) "Handbook verkeersveiligheid", Kennisplatform Crow.

Aquilué Junyent, I. and Stummvoll, G. (2014) "Bellvitge: Unexpected Success - Against all Odds" (COST-action TU 1203 case study).

Aramburu, M., Ezquerra, S., Garcia, D. and Villaplana, L. (2009) "Estudi de les polítiques d'espai públic a l'entorn metropolità de Barcelona. El Cas de Bellvitge a l'Hospitalet i La Pau i Lloreda a Badalona". Bellaterra, Barcelona: Universitat Autònoma de Barcelona \& Institut de Govern i Polítiques Públiques.

Associació de Veïns de Bellvitge. (2005) Bellvitge 40 anys d'història, 1965-2005. L'Hospitalet de Llobregat (Barcelona): Associació de Veïns de Bellvitge.

Campkin, B. (2013) "Remaking London: Decline and Regeneration in Urban Culture". I.B.Tauris, London.

Crowe, T. D. (2013) "Crime prevention through environmental design". Woburn, MA: ButterworthHeinemann. Revised edition of 1991 version.

De Villeneuve-Esclapon Aubigny (Baronne d'), J. and Giraudoux, J. (1943) La charte d'Athènes, Plon, Michigan, USA.

Dijk, B. van and Soomeren, P. van (1986) "De Bijlmermeer; criminaliteit en verbeteringsplannen". Amsterdam: Van Dijk, Van Soomeren en Partners.

Gifford, R. (2007) "The Consequences of Living in High-Rise Buildings". Architectural Science Review Volume 50, Issue 1,p3.

Habraken, N.J. (2000) "The structure of the Ordinary; Form and Control in the Built Environment". MIT Press.

Hootsen, C.L. (2006) "Ontwerp tegen sociale onveiligheid in de Bijlmermeer. Bouwkundige maatregelen tegen criminaliteit en onveiligheidsgevoelens in en rond hoogbouwflats". C.M. KanInstituut, Faculteit der Maatschappij-en Gedragswetenschappen, Universiteit van Amsterdam. 
INE (1991) Censo de población y viviendas 1991. Madrid: Instituto Nacional de Estadística.

INE (2001) Censo de población y viviendas 2001. Madrid: Instituto Nacional de Estadística.

Instituto de Criminología (1986) "La Problemática de la droga en España: análisis y propuestas político-criminales". Madrid: Editoriales de Derecho Reunidas.

Jacobs, J. (1961) Death and life of great American cities. New York, NY: Vintage Books.

Jeffery, C. R. (1971) Crime prevention through environmental design. Beverly Hills: Sage Publications.

Klundert, W. van de (2014) "Bijlmermeer Regenerated". Dissertation Westminster University London, London, United Kingdom (available from www.e-doca.eu).

Kube, E. (1982) Städtebau, Wohnhausarchitektur und Kriminalität. Prävention statt Reaktion. Heidelberg: Kriminalistik Verlag.

Lukas, T. editor (2007) "Crime Prevention in High-rise Housing. Lessons from the Crime Prevention Carousel (Sharing Good Practice in Crime Prevention, based on the Evaluation of Physical Rehabilitative and Social Schemes in Problematic Urban Areas in Member and Accession States)", PART A: Final Report AGIS (JAI/2004/AGIS/164). Max Planck Institute for Foreign and International Criminal Law, Freiburg.

Newman, O. (1980) Community of Interest. New York: Doubleday.

Newman, O. (1972) Defensible space: Crime prevention through urban design. New York: Macmillan.

Pressman, J. and Wildavsky, A. (1973) Implementation, Berkeley: University of California Press.

Soomeren, P. van (1995) "Dream, nightmare and awakening - Experiences at the crossroads of town planning, architecture, security and crime prevention", DSP-groep, Amsterdam/Tokyo.

Soomeren, P. van, Klundert, W. van de and Kleuver, J. de (2014) "High-rise in trouble; Dream, nightmare and awakening: the case of the Bijlmermeer in Amsterdam" (COST-action TU 1203 case study).

Soomeren, P. van et al: "The Bijlmermonitor" (statistics, survey, etc.) The Bijlmermonitor is available for 1997 to 2001 yearly issues and (bi-yearly), 2003, 2005, 2007 and 2009 (downloads available in Dutch from www.DSP-groep.nl).

Turkington, R., Kempen, R. van and Wassenberg, F. (eds.) (2004) "High-rise housing in Europe Current trends and future prospects". Housing and Urban Policy Studies 28. OTB Research Institute for Housing, Urban and Mobility Studies Delft University of Technology, Delft, The Netherlands.

Wassenberg, F. (2006) "The integrated renewal of Amsterdam's Bijlmermeer high-rise", Informationen zur Raumentwicklung Heft 3/4, pp. 191-202.

Wassenberg, F. (2013) "Large housing estates: ideas, rise, fall and recovery. Bijlmermeer and beyond". Delft: Delft University Press.

Yuen, B. et al.(2011) High-Rise Living in Asian Cities. Springer, Netherlands. 
Zimmerman, N. (2007) Foreword in Lucas (see also:http://www.dspgroep.eu/newsitem/ 688/the_crime_prevention_carousel.html).

The text of this article is based on two case studies:

- Inés Aquilué Junyent and Guenter Stummvoll: Bellvitge: Unexpected Success - Against all Odds (COST-action TU 1203 case study).

- Paul van Soomeren, Willemijn van de Klundert and Justin de Kleuver: High-rise in trouble; Dream, nightmare and awakening: the case of Bijlmermeer in Amsterdam (COST-action TU 1203 case study).

Link for the research on Bijlmermeer and Bellvitge:

http://costtu1203.eu/downloads/cost-tu1203s-results/

i

Note $_{7}$ The car owners route in Bijlmermeer: drive from a +1 level road (cars only) to a parking building, walk through a public covered corridor to a lift, go up and walk to the apartments.

ii

Note ${ }_{7}$ In the Netherlands housing associations (run by managers) let dwellings to tenants. This Bellvitge Housing association represents a collective of apartment owners.

iii

Note 7 Housing Association of Bellvitge had its own facsimile, published during the 1970s, whose authors were Luchadores Anticapitalistas de Bellvitge. The publication's title was Bellvitge en lucha informa... (Bellvitge in fight informs...).

iv

Note 7 All demographic data could be found in the statistical year-books of l'Hospitalet del Llobregat. See: http://www.I-h.cat/laciutat/265286_1.aspx?id=1

$\mathrm{v}$

Note ${ }_{7}$ https://www.government.nl/topics/drugs/contents/how-does-the-law-distinguish-between-soft-and-hard-drugs vi

Note vii As can be seen in the Bijlmermonitor and as was presented to the local government in 2011: http://www.veilig-ontwerp-beheer.nl/activiteiten/nederland/SVOBbiilmerjuni2011Compatibiliteitsmodus.pdf (slide18) 